\title{
EXTRATERRITORIALITY IN CHINA
}

By F. E. HincKLEY,

District Attorney of the United States Court for China, Shanghai.

By largely similar treaties with eighteen of the powers, China has granted full exemption from her territorial jurisdiction in favor of the nationals of these powers residing or traveling in China, and over the property of these nationals, real and personal, situate in China. These eighteen, in order of the dates of their first treaties, are: Russia, by a treaty of 1689 for the Mongolian border; the United States by the first of the modern and distinctly extraterritorial treaties - a treaty negotiated by Caleb Cushing, afterwards United States Attorney-General, whose draft was so excellent as to have been generally followed as a model in the negotiations of the treaties of other powers with China; then Great Britain, France, Norway and Sweden (now as two powers with one treaty), Germany, Portugal, Denmark, Holland, Spain, Belgium, Italy, Austria-Hungary, Japan, Peru, Mexico, and Brazil. These are practically all of the powers that have treaties of any nature with China. Even if there were commercial treaties with other countries containing most-favored-nation clauses, such clauses would probably not extend the extraterritorial exemption; yet it has occurred that when powers without extraterritorial treaties have permitted exercise by a friendly power of jurisdiction over their nationals, for instance, jurisdiction over Greeks by consuls of France, China has acquiesced, and it has also occurred that in isolated cases a non-treaty consul, like the consul of Cuba, has adjudicated over his nationals in China without effectual protest by the Chinese government; but such friendly and non-treaty jurisdiction is a negligible minimum. The substantial fact is that China has continuously maintained her jurisdiction sovereignty excepting as specifically abrogated by treaty.

The counterpart of this treaty exemption from Chinese jurisdiction is the agreement to extend the respective national jurisdictions into China. The rule of the treaties is that a defendant is sued in the court of his own nationality, and by mutuality of practice this rule is extended in favor of a plaintiff of whatever foreign

(97) 
nationality he may be. The jurisdiction is mostly exercised by consuls at the various ports. Some of the powers have but one or two consuls for all China. Few of the consuls are men of any training or experience in the law. In some cases a consul may be assisted by one or more assessors, and, with them, the consul judges both of law and fact. Most of the foreign jurisdictions are but meagerly developed. The larger powers, however, have special legislation as to their courts in China. Great Britain and the United States have each established higher and general courts independent of their consular systems, respectively known as $\mathrm{H}$. B. M. Supreme Court for China and the United States Court for China. These two higher courts exercise their jurisdiction mostly at Shanghai, where court business readily concentrates. They hold sessions in other consular cities in China when the public interest requires. They exercise general appellate and certain supervisory powers. They and the systems of courts of which they are the head are the highest and most extensive development of extraterritorial courts in the world. The United States Court is analagous to a federal circuit court, though with wider jurisdiction inclusive of the jurisdiction of a higher state court, and the British Supreme Court has the jurisdiction of a high court of justice in England.

Another form of court has been evolved by time and necessity but without close adherence to the treaties. This is the so-called mixed court. It is a court existing in each of the consular cities. It is for the trial of Chinese defendants. A Chinese magistrate presides over it and with him sits a foreign assessor, regularly of the nationality of the plaintiff. The consul himself may be the assessor, but in the main cities a vice-consular officer, ordinarily a Chinese linguist, is assessor. At Hankow the Chinese magistrate goes from one consulate to another to hold trials on regular days. The practice varies in different cities. At Shanghai the mixed courts are extensive establishments, with three or four Chinese magistrates, the criminal cases being heard almost entirely in the presence of British, American, German and French assessors, the French having a separate court. It is also distinctive of Shanghai that the assessors there, while having, as in other cities, strictly but a right to be present and to object in cases involving their own nationals as plaintiffs, in effect direct what the judgment in every criminal case shall be and have assumed an almost 
equally preponderating authority in civil cases that involve their respective nationals as plaintiffs. The premise is taken that criminal jurisdiction exercised in or respecting the international foreign settlement at Shanghai involves such foreign interests, whoever the complainant may be, that a foreign assessor representing those interests has an implied right to appear and to direct the judgment. There is practical advantage in this system, however far it departs from the letter of the treaties. The mixed court at Shanghai is but a very low court in the jurisdiction systems of all the powers that have to do with it, yet it is the busiest of all the courts at Shanghai and it adjudicates actions involving very large values and most important personal interests.

The consular courts also are far from having reached a development adequate to present conditions. They mostly rest upon treaties made soon after the British war of 1842 , and renewed with little change soon after the British and French war of $185^{8}$. In those years the foreign inhabitants of China were men in charge of large business concerns and missionaries and the immediate dependents of both, and all foreigners were located in or near to the principal ports; but in I9II there are in China all classes of Western society, and foreigners resident in China number many thousands. There are also many tourists. No restriction on immigration excepting that of health inspection exists. The most cosmopolitan aggregations and combinations populate the ports and penetrate to remote places. The foreign population of China exclusive of the Japanese and Russians in Manchuria, must be well above 30,000. These are mostly merchants and missionaries. There are few men of the professions and of course few or none of the large classes of industrial and agricultural populations familiar at home. Adventurers and vagrants, gamblers and prostitutes infest the ports, affirming or disclaiming their nationality according to the lenience or severity of their national authorities. Foreign missionary societies enjoy a treaty privilege of acquiring land for mission purposes both in the consular cities and in the interior. Foreign merchants have extended their trade into the most distant regions. The last twenty years have seen an increase at high ratio of all sorts of contractual relations between foreigners and Chinese. Partnerships and companies, numerous and varied in nature, having a foreign name and protection but involving 
Chinese members and not infrequently being controlled by Chinese, have come into being without adequate executive and jurisdictional regulation. In fact the requisites of the extraterritorial communities in China have come far to exceed the legislative provisions made for them. The British interests in China are probably more adequately provided for than any other.

British legislation has been founded upon the Foreign Jurisdiction Acts, the latest of which is the Act of 1890 . This Act is very brief, general and fundamental. On it are based the Orders in Council amplifying and perfecting the system. Orders in Council have been frequent and they seem to be readily obtained. Besides, there is the often and very timely exercised authority of the British Minister at Peking to make regulations of the nature of substantive law and having the force of law until and as modified by the higher legislative authority. By this power of the Minister local and temporary conditions usually of emergency nature are regulated. But the control of the jurisdictional system, that is of court procedure and, as shown mainly in the well and lengthily developed Rules of Court, of the operation of the courts generally, rests primarily with the Judge of the British Supreme Court for China. This court was organized in I867. Unfortunately there is no collected series of its reports, and reference must be had to the reports published from 1867 to date in the official organ, the North China Herald. The long and eminent standing of the British Court and its wisely directed and wide-reaching activities have well and effectually protected, regulated and promoted British interests in China.

The British Crown Colony of Hongkong, situate at the commercial portal of South China and having, with other branches of government, a Supreme Court, has adjudicated many of the most important cases arising out of extraterritorial relations with the Chinese and has also largely enhanced British prestige. This court has of late years a collected series of reports. British companies in China are regulated by Hongkong Ordinances. This arrangement may in time be modified to meet difficulties due to the fact that business at Shanghai has now become proportionately greater, and authority may be given to register and regulate companies through British officials at Shanghai; but the facility and security of registration and regulation through British colonial offices at Hongkong in the last half century has brought under the British 
flag vast foreign business in China, especially German, American and Chinese.

The German government has now under consideration the establishing of a higher and general court for all Germans in China. It is also considering a modification of companies' statutes so as to favor the association or incorporation of companies in China under German law with registration in Kiaochau, the German leased area in North China.

The United States government has no specific legislation as to companies in China. The usual way of organizing American firms has been to register the articles of association at one of the consulates or to incorporate under the Hongkong Ordinances. In a few cases there have been incorporations under home jurisdictions as of Arizona or Delaware or the District of Columbia, and this is easily done under some jurisdictions. The degree of liability of such corporations in China is not clear. There is some doubt whether the incorporation statutes of the home jurisdictions were intended for or can be held to have force with regard to business firms conducting their business entirely outside of the continental territory of the United States. What is the status of home corporations doing business under American jurisdiction in China has not been determined. With a number of such corporations doing large business, this backward condition of the law, though strange, is an evidence of their good management and fair dealing. It is a tribute also to American diplomatic ard consular officials who have conducted negotiations with the Chinese government and its officials affecting these companies. On the other hand, the ease with which unscrupulous persons have at times and in certain consular districts formed themselves into companies largely with Chinese capital under an American name and American consular recognition has not been creditable and has been a detriment to legitimate business.

The repression of crime in so large and so fluctuating a foreign population as now exists along the China coast is one of the chief reasons for maintaining the extraterritorial jurisdictions at a high degree of efficiency. Vagrancy is more difficult to deal with in a land where few Europeans do manual labor and where honesty and respectability are presumed to belong to foreigners generally. Yet the almost daily convictions, at Shanghai for instance, of lowclass petty offenders have at last necessitated the stone-pile and 
the work-house. In most of the consular courts in Shanghai the only penalties for vagrancy have been fairly comfortable imprisonment and further charity. Deportation is expensive and impracticable except as to the more serious offenders. In other grades of society there is now and then a criminal offender whose offense is not easily prosecuted because of the extraordinary local difficulties of securing convicting evidence. The consuls and other court officials are relatively-few, and measures of detection and proof of crime feasible in home jurisdictions entirely fail in China where the jurisdictions are so many and so complex. Of crimes of violence by foreigners of the degree of murder, burglary, robbery, arson and rape there are very few. Commercial wrongs, such as embezzlement and obtaining goods on false pretenses are not infrequent, and at times there is forgery. Gambling at roulette for foreign patronage and at a Chinese game called pai-chu for Chinese patronage has been opened whenever the vigilance of the authorities has relaxed or whenever with the connivance of unscrupulous persons, even of officials and lawyers, a ruse or tangle of jurisdiction or evidence could be devised. Prostitution among foreign men and women has given the China coast an evil reputation, but there has been rigorous dealing with this vice at Ma-illa and in American jurisdiction in China. At Shanghai liquors are sold in bawdyhouses without municipal licenses and the income from this sale is said to be the principal income of these places. The compulsory registration of prostitutes in the consulates of their nationalities would, by definitely fixing jurisdiction over them, aid at least in placing responsibility for their indecencies.

For the apprehension and custody of criminal offenders there are attached to the consulates of the leading powers in the principal cities officers in most cases known as marshals, and at Shanghai there are prisons and prison-keepers. British long term prisoners go to Hongkong; those of other nationalities are usually sent home. The principal foreign municipalities have police or constables; the police in the International Settlement at Shanghai have on their rolls about 250 foreigners, almost all British, 500 Sikhs and 1,200 Chinese. The foreign army, marine and navy contingents on service in China or Chinese waters may be called upon for assistance when necessary. The Chinese have authority under the treaties and customs to arrest, except in foreign settlements, a foreign crim- 
inal offender and bring him to the nearest consulate of the offender's nationality. Thus an American charged with homicide was brought, in 1908, by the Chinese from the borders of Thibet to Chungking in central China, 600 miles, and thence, with the witnesses, to trial in Shanghai, I,200 miles. He was acquitted on a finding of accidental homicide, but had he been convicted to serve imprisonment for more than a year, he would, in usual course, have been sent thousands of miles farther to a federal prison in the United States.

Extradition of fugitive offenders to and from China is not provided for by treaty. China is the greatest and most accessible area in the world not yet protected against the coming and going of criminals. A criminal slips aboard a steamer at Shanghai and is off to Japan or Hongkong leaving the prosecuting officers to contrive means not provided for in the law to bring the fugitive to justice. A British offender in China can be'returned from any British jurisdiction because extradition acts are extended to British jurisdiction in China. But it has been ruled that the British and American extradition acts do not reciprocally extend to their extraterritorial jurisdictions-a ruling which on the principles of law involved appears rather too narrow. It is a surprising and embarrassing fact that an American offender cannot be extradited to or from the United States from or to China, though United States jurisdiction is as absolute over him in one place as the other. Legislation, which could be in a simple form, is requisite; the United States extraterritorial jurisdiction in China should, for the purposes of its administration solely, be designated as a jurisdiction of the same standing as federal jurisdiction in one of the territories of the United States, and the extradition statutes should be extended to this China extraterritorial jurisdiction just as they were to the Philippine Islands.

Legislation is also needed for better establishing the jurisdiction and supervising the administration of estates of American decedents in China. The number of estates, their value, the complexity of the jurisdiction, the want of the assistance of American lawyers except at Shanghai and Tientsin, and the undeveloped probate procedure have made this feature of the jurisdiction the most constant business before the American courts in China and have put upon executive officials of the courts an extraordinary respon- 
sibility. All estates of a value above $\$ 500.00$ are, by judicial interpretation of a statute, required to be formally administered under decrees and orders of the United States Court for China. Such estates are reported from the consulates and the initial procedure for bringing them into the court is usually taken by the clerk of the higher court acting on instructions from the judge. Many of these estates are not much in excess of $\$ 500.00$ and such are likely to be the estates of missionaries residing in out-ports or in the interior whose families and beneficiaries prefer as simple and inexpensive an administration as can be had. For this class of estates the gratuitous assistance of the clerk of court is well deserved and much appreciated, and it has the advantage of facilitating and of tending to standardize the procedure. Such assistance consuls had previously given under their general instructions and by customs special to this jurisdiction. This feature of the duties of the clerk of the higher court could very well be formally recognized by making him a registrar of probate with statutory functions including some of the functions of a public administrator. The larger estates have been administered without difficulty through the exceptional care to each step of the procedure which has been given by the judge of the higher court. This has enabled him as the judge of a court established only in 1906 to familiarize himself with every feature and problem relating to the administration of American estates in China; but it is a burden which, with the increase of his duties in connection with the other features of the jurisdiction, and with the development of probate procedure will distribute itself, as it does in home jurisdictions, amongst the lawyers engaged by executors and administrators especially now that there are a number of well established American lawyers in Shanghai and other ports.

The entire probate jurisdiction, however smoothly it has thus far operated, needs to be better established by statutory enactment. There never has been a specific grant of the jurisdiction to the American Courts in China. The consular courts had for many years customarily exercised probate jurisdiction. The United States Court for China has supervisory powers over consuls in their executive duties with respect to estates of Americans in China. The first judge of the court, Judge Lebbeus R. Wilfley, decided that in granting common law jurisdiction to the courts in China, Congress had granted such probate jurisdiction as the common law courts of England had reserved to themselves, notwith- 
standing that when the colonies became independent of the mother country, probate jurisdiction was being exercised principally by the ecclesiastical courts and notwithstanding that in the colonies, as later in the states, probate jurisdiction was exercised only upon specific statutory grant. This decision, and any other decision regarding the probate jurisdiction of our courts in China, has not been reviewed by an appellate court in the United States. Legislation is nevertheless apparently necessary.

In another decision Judge Wilfley established that there had been no grant of jurisdiction of matrimonial causes. The distinction lay in the fact that the ecclesiastical courts of England in the time of our colonial dependence had exercised this jurisdiction exclusively. In the United States jurisdiction of matrimony rests absolutely on statute. Consequently divorce cannot be had in American jurisdiction in China. As a matter of public policy, and considering that courts of other foreign jurisdictions in China, either have only a limited jurisdiction of matrimonial causes and practically never exercise the jurisdiction, it is unquestionably better that no American court in China should have more than such a limited jurisdiction. The American consular courts, however, had, prior to the creation of the higher court that took over the main jurisdiction, granted absolute divorces. On the other hand the lack of some such jurisdiction has proved a severe hardship in several instances of non-support of a wife and of desertion. What power, if any, the courts would exercise as courts of equity for relief in such cases has not been tried.

Other leading decisions by Judge Wilfley were as follows: Domicil is acquired in extraterritorial jurisdiction in China on principles analogous to acquisition of domicil in a jurisdiction at home. The term "common law" in the statutes establishing extraterritorial courts in China is interpreted to mean those principles of the common law of England and the statutes passed in aid thereof, including the law administered in the equity, admiralty and ecclesiastical tribunals, which were adapted to the situation and circumstances of the American colonies at the date of the transfer of sovereignty, as modified, applied and developed generally by the decisions of the state courts and by the decisions of the United States Courts and incorporated generally into the constitutions and statutes of the states. The United States Court for China, though analogous in some respects to a federal court, has no jurisdiction 
under the federal bankruptcy act, the enforcement of that act having been restricted to certain $\cdot$ federal courts.

A bankruptcy case involving large amounts and in which the principal creditors were a German bank and a Chinese bank, one having actual possession and the other claiming constructive possession of assets, was adjudicated by Judge Rufus $H$. Thayer, who succeeded Judge Wilfley late in I908. Judge Thayer exercised jurisdiction on the basis of common law insolvency, but, under the circumstances, and after consent of the creditors, the insolvent having left the jurisdiction, he adjudicated the case in much the same way as an arbitrator might do in an effort to effect substantial justice among the parties.

Judge Thayer's decisions have been numerous and important. It is difficult briefly to state how much they have defined and improved the jurisdiction. In a homicide case in which a Chinese official had a treaty right to be present and to question witnesses, the policy and procedure under a somewhat difficult treaty provision were so controlled as to form an excellent precedent comporting with the high authority of the court and declared by the superior Chinese authorities to be eminently satisfactory to them as a fulfilment of the treaty. In the estate of a decedent who had held real property in trust for a Chinese, Judge Thayer held that a question of title was not to be determined in the court having jurisdiction of the estate, but in the court of the Chinese who had granted the trust. The law governing a contract when not stipulated by the parties he has held to be the law of the nationality of the party sued. Jurisdiction of real property in China in whatever foreign consulate it is recorded follows the jurisdiction of the person who holds the fee simple or similar title. The nature and requisites of appeals from consular courts have been ruled upon. Jurisdiction has been taken of three civil cases against consuls concerning performance of official duties. A consular court marshal and a legation stenographer have been tried for embezzlements. The court has, on the principles involved, ruled adversely to a claim of foreign nationality set up as a bar to a criminal action. It has upheld the local regulation of the nature of a statute of limitations in a criminal case in place of the federal statute. It has found void a local regulation of the Minister as to vagrancy, and in its stead has followed and differentiated the decision of the Court of Appeals as to the effect had in China by federal legisla- 
tion for the North American territories and the District of Columbia.

Appeals lie from the consular courts to the United States Court for China and from the latter to the United States Circuit Court of Appeals at San Francisco and thence to the United States Supreme Court. Appeals from the United States Court for China have been few, especially since the court has become well established. The main appellate decisions have been as to right to bail, as to what constitutes assault with a deadly weapon, as to procedure of writ of error, and, what appears most important of all, as to the significance of the term "laws of the United States" to be administered in the courts of the United States in China. In the latter decision-Biddle $v$. United States-on the error assigned that obtaining money on false pretenses was not a crime under common law or under the laws of the United States available in China, the Court held that laws enacted for jurisdictions where the United States exercised exclusive jurisdiction, as in the territory of Alaska or the District of Columbia, or the military and naval reservations in the states, were laws of the United States available for the definition of the offense of obtaining money on false pretenses in China. This decision was most far reaching and its full effect has been difficult to comprehend. The resulting conflict of definitions of statutory offenses remains for further determination.

A most important habeas corpus case, that entitled In re Ross, was decided by the United States Supreme Court in I89o. It arose on a claim of right of jury trial for the defendant on a charge of homicide. The opinion of the court, prepared by Justice Stephen J. Field, who had had earlier study of extraterritoriality as Circuit Court Justice in California through his decision of a case on appeal from the Consular Court at Canton, examined into the fundamentals of the jurisdiction and disclosed the nature of the consular courts as courts intended to aid in fulfilling our national treaty obligations and as such having a special and limited jurisdiction, favorable to a defendant as being exercised on principles similar to those of his home jurisdiction even though unfavorable to him as not having certain home privileges, such as trial by jury, vouchsafed to him. No court opinion is more enlightening as to fundamental principles of extraterritoriality than Justice Field's opinion In re Ross.

The extraterritorial courts of the several powers in China are 
closely related to their consular systems and are under the foreign affairs departments of the respective governments, yet in the exercise of their purely judicial functions the judges and the consuls constitute independent courts with their decisions not reviewable except by the higher courts. The incumbents of the principal offices in the courts should be and generally are men not only thoroughly trained and of experience in the law, but also men of large acquaintance with conditions in China and of special aptitude for maintaining relations with Chinese and other foreign officials. The rapid development of foreign interests in China and of Chinese relations with foreigners incessantly raises novel and complex problems. To maintain justice, secure protection and promote friendly relations is the object of the treaty extraterritorial courts; it is an object of the first importance, and under the conditions in China it requires for its attainment a high grade of court personnel and a highly developed system of courts and of statutes and decisions defining the law.

China is developing her own system of law and of courts on European models. This development has been slow and irregular. Yet it may, under the present changes of government, come rapidly and permanently. In their commercial treaties of 1902 and 1903 Great Britain and the United States agreed to give every assistance to the reform of the judicial system of China and to be prepared to relinquish extraterritorial rights when satisfied that the state of the Chinese laws, the arrangements for their administration and other considerations warranted so doing. To foreign residents in China the time when relinquishment of jurisdiction will prove feasible seems far distant. The extraterritorial system has advantages, but in modern conditions it is at best anomalous and unsatisfactory as a means of doing justice and it tends to fall of its own complexity and weight. Only the larger powers can afford to maintain it and only they appear able readily to adapt their systems of laws and courts to the rapidly changing conditions. All relations with China and with the Chinese will be better when China shall have resumed her full territorial sovereignty and risen to the place of international power which her vast territory and resources, and her great people and newly progressing government shall justify and command. 